\title{
ARTICLE 47(2) OF THE ROTTERDAM RULES: SOLUTION OF OLD PROBLEMS OR A NEW CONFUSION?*
}

The Rotterdam Rules, adopted by UNCITRAL in 2008, address a number of issues that have not been regulated by previous international conventions, such as the delivery of goods and the right of control. The ambitious and innovative approach of the Rotterdam Rules has attracted much international debate. This article aims at contributing to this debate by discussing the provisions related to the delivery of goods. The main focus is on Article 47(2), one of the most controversial provisions of the Rules. The article analyses in detail this legislative provision, its rationale and possible impact on the law governing the carriage of goods and international sales law.

Keywords: international conventions; carriage by sea; transport documents; negotiable documents; delivery of goods.

\section{INTRODUCTION}

On 3 July 2008, UNCITRAL approved the United Nations Convention on Contracts for the International Carriage of Goods Wholly or Partly by Sea (the Rotterdam Rules) which was finally adopted by the UN General Assembly on 11 December 2008. ${ }^{1}$ This new UNCITRAL legislation has the ambitious goal of restoring the uniformity of the law governing the international carriage of goods by sea.

* This article was first published in the Journal of International Maritime Law ((2012) 18 JIML issue 5), published by Lawtext Publishing Limited www.lawtext.com. It is based on a presentation given at the Max Planck Institute in Hamburg on 15 October 2012 as part of the Hamburg Lectures in Maritime Affairs. The author is grateful to Jan Ramberg and Erik Rosag for their constructive comments and suggestions which helped to refine this article. The author remains responsible for any errors that may remain.

** Professor Časlav Pejović, Department of International Legal Studies, Faculty of Law, Kyushu University, Japan, E-mail: pejovic@law.kyushu-u.ac.jp.

1 The United Nations Convention on Contracts for the International Carriage of Goods Wholly or Partly by Sea (the Rotterdam Rules) www.uncitral.org/pdf/english/texts/transport/rotterdam _ rules/09-85608_Ebook.pdf. 
Presently, there are three international regimes governing the carriage of goods by sea: the Hague Rules, ${ }^{2}$ the Hague-Visby Rules ${ }^{3}$ and the Hamburg Rules. ${ }^{4}$ If widely adopted, the Rotterdam Rules may be able to replace these three conventions and restore uniformity to the law.

The Rotterdam Rules address a number of issues that have not been regulated by previous international conventions. There are completely new sections which cover the delivery of the goods and the right of control. The growing use of nonnegotiable documents and documents in electronic form has drawn the attention of legislators to these areas that previously had been ignored by all of the international conventions governing the carriage of goods by sea. This innovative approach was probably motivated by the need to adjust the international regime governing the carriage of goods by sea in such a way as to cope with various modern developments, such as the increased importance of container transport, logistics and electronic commerce.

The ambitious and innovative approach of the Rotterdam Rules, which in some sections departs from certain well-established principles, has attracted lively international debate. This text aims at contributing to this debate by discussing provisions related to the delivery of the goods. Main focus is on article 47(2) which is one of the most controversial provisions of the Rotterdam Rules. Here it is analyzed in detail including its possible impact on international sales law.

A number of complex questions can be raised with respect to article 47(2). In maritime law, there is a well-established rule that the carrier must not deliver the goods in any way other than against the presentation of an original bill of lading. It may therefore be asked why Article 47(2) has departed from this fundamental principle? Can a document that does not require presentation against delivery of the goods be considered a negotiable document, or have the Rotterdam Rules created a new type of negotiable document which does not have to be presented to the carrier? Was it really necessary to invent a new transport document that would be called negotiable while, in fact, it would not be negotiable in the usual meaning of the term as it would lack an essential feature of negotiable documents, namely surrender in exchange for the goods? How would this affect the role of transport documents in international trade? Would a bank be willing to pay under a letter of credit against a negotiable document which provides that delivery can be made without its presentation? Is Article 47(2) the best solution

2 International Convention for the Unification of Certain Rules of Law relating to Bills of Lading (The Hague Rules) and Protocol of Signature, signed in Brussels on 25 August 1924 (entered into force on 2 June 1931).

3 Protocol to Amend the International Convention for the Unification of Certain Rules of Law Relating to Bills of Lading 1968 (entered into force on 23 June 1977).

4 United Nations Convention on the Carriage of Goods by Sea ("the Hamburg Rules"), signed in Hamburg on 31 March 1978 (entered into force on 1 November 1992) UN.Doc.A/Conf. 8915. 
to the existing problem of the delivery of goods without the surrender of a negotiable document? Was this Article necessary at all? These questions will form the focus of the discussion.

\section{GENERAL PRINCIPLES RELATING TO DELIVERY OF GOODS}

All previous international conventions governing the carriage of goods by sea have failed to regulate the issue of the delivery of goods. Differences among national laws and different practices may have been the reasons why this issue was left aside by the drafters of those conventions. At present, the rules on the delivery of goods are still based on domestic laws.

In maritime law, there is a well-established rule that the carrier can deliver the goods at the destination only against the surrender of a bill of lading by the consignee. Once the master has issued the bill, the carrier has an independent, contractual obligation towards the bill of lading holder which is derived from the nature of the bill of lading. Since the bill of lading is a negotiable document, its holder is entitled to require that the goods are delivered to him.

As long as the consignee can obtain a bill of lading before the goods arrive, there should be no problem for him to present it before delivery. However, in practice, for various reasons, it is often the case that the ship arrives at the port of destination before the consignee has obtained the bill of lading. In such situations, waiting for the bill of lading may cause numerous problems for all parties involved. In order to solve this problem, the practice of delivering the goods without the production of a bill of lading has been developed. This practice, however, may also cause a number of problems particularly for the consignee and the carrier. ${ }^{5}$

The consignee may find himself in a difficult position, because he may not be able to receive the goods at the port of destination even though he performed properly all his obligations. In order to receive the goods the consignee may have to provide a letter of indemnity to the carrier often supported by a bank guarantee, which can expose the consignee to considerable expenses.

If the carrier delivers the goods without the surrender of a bill of lading, he does so at his own risk. If the goods are delivered to a person who was not entitled to receive them, the carrier will be liable for breach of contract and for conversion of the goods. ${ }^{6}$ In such cases the carrier may be deprived of the benefit of limitation of liability and may not be able to get indemnification from the P\&I clubs.

C Debattista Bills of Lading in Export Trade (Tottel Publishing 2008) 38-39.

6 Barclays Bank Ltd v Commissioners of Customs and Excise [1963] 1 Lloyd's Rep 81, Sze Hai Tong Bank Ltd v Rambler Cycle Co Ltd [1959] 2 Lloyd's Rep 114. See also Mobile Shipping Co v Shell Eastern Petroleum Ltd (The Mobile Courage) [1987] Lloyd's Rep 655. 
There are some exceptions to the rule that the consignee must present the bill of lading before delivery. The carrier might deliver the goods without the production of a bill of lading if it is proven to his reasonable satisfaction both that the person demanding delivery was entitled to possession of the goods and that there was some reasonable explanation for what happened to the bill of lading.7 Carriers should, however, be very cautious with respect to this exception. ${ }^{8}$

\section{BACKGROUND TO THE RULES ON THE DELIVERY OF GOODS}

The first issue that needs explanation relates to the rationale for the rule that the carrier must deliver the goods against the bill of lading. It seems that the reasons for such an obligation on the part of the carrier are sometimes not properly understood. Hence, in order to examine the issues related to the delivery of the goods against the surrender of the bill of lading, the reasons for this rule should be examined.

The nature of the bill of lading as a document of title is directly related to the issue of the delivery of the goods. ${ }^{9}$ At common law, the bill of lading is characterized as a document of title, which means that the person in possession of it is entitled to receive, hold and dispose of the bill of lading and the goods it represents..$^{10}$ In civil law systems, there are documents corresponding to documents of title, but the approach is different. While under common law there are several types of documents, such as negotiable documents, negotiable instruments and securities, in civil law all these documents are covered by a single type of document. ${ }^{11}$ The "Wertpapiere" in German law, "titres" in French law, "titoli di credito" in Italian law, "yuka shoken" in Japanese law and so on can be defined as "documents of value" which contain certain rights embodied in the documents themselves (such as the right to obtain delivery of the goods specified in the document, or the right to payment of a certain sum of money). They confer upon the holder the right to transfer these rights to third parties by transferring the documents.

7 SA Sucre Export v Northern River Shipping Ltd (The Sormovskiy) [1994] 2 Lloyd's Rep 266.

$8 \quad$ Motis Exports v Dampskibsellskabet AF 1912 [2000] 1 Lloyd's Rep 121; affirming [1999] 1 Lloyd's Rep 837. See also East West Corp v DKBS 1912 [2002] 2 Lloyd's Rep 182 at 205.

9 The author has examined this issue in more detail in C Pejovic "Documents of Title in Carriage of Goods by Sea: Present Status and Possible Future Directions" (2001) JBL 461.

10 The term "document of title" was first defined by section 1(4) of the English Factors Act as follows: "The expression 'document of title' shall include any bill of lading, dock warrant, warehouse-keeper's certificate, and warrant or order for the delivery of goods, and any other document used in the ordinary course of business as proof of the possession or control of goods, or authorizing or purporting to authorize either by endorsement or delivery, the possessor to transfer or receive goods thereby represented".

11 This difference between civil law and common law systems is probably a result of the different nature and approaches of these two legal families. While civil law often relies on broad concepts, common law has a preference for narrow concepts. 
By means of a legal fiction, the bill of lading is deemed to represent the goods, so that possession of a bill of lading is equivalent to possession of the goods. Strictly speaking, the right to obtain the goods from the carrier is not based on the contract of carriage, but on the lawful possession of the bill of lading. The bill of lading enables its lawful holder to use it to obtain physical delivery of the goods at the port of destination, as well as to dispose of them during transit by transferring the bill of lading.

The effect of the transfer of a bill of lading is a result of the special character of the object of sale - goods carried by sea - such that it is impossible to make a physical delivery of the goods while they are in transit to the buyer. The delivery has to be carried out through the carrier as an intermediary, who receives the goods from the shipper (typically the seller) and is bound to deliver them to the consignee (typically the buyer) in exchange for the bill of lading. In fact, the seller performs the goods delivery by transferring the bill of lading to the buyer, thereby transferring to the buyer the right to demand the delivery of the goods from the carrier at the port of destination. Through the contract of carriage, evidenced by the bill of lading, the carrier undertakes to deliver the goods as described in the bill of lading to the consignee to whom the shipper transfers the bill. After the bill of lading has been transferred to the consignee, it represents the contract between the carrier and the consignee who has an independent right against the carrier to demand delivery of the goods as described in the bill of lading.

The shipper can retain control over the goods after he has delivered them to the carrier, if the bill of lading is issued on his order, until the buyer (the consignee) pays the price or accepts the bill of exchange. The consignee cannot receive the goods from the carrier without the bill of lading, and he will not obtain the bill of lading before he pays the price or accepts the bill of exchange. The shipper will lose control over the goods and the right to dispose of them at the moment he transfers the bill to a transferee. By acquiring the bill, the consignee acquires control over the goods and constructive possession. Hence, the rule that the goods must be delivered only against the bill of lading serves to protect against the risk that the goods are delivered to someone who is not entitled to receive them. This rule protects both the carrier and the persons entitled to receive the goods.

\section{DELIVERY OF GOODS UNDER THE ROTTERDAM RULES}

In contrast to all previous conventions, the Rotterdam Rules expressly regulate the delivery of goods. Article 11 first provides for the carrier's obligation to deliver the goods to the consignee. This obligation is also mentioned in Article 13(1). Most importantly, chapter 9 is dedicated to the delivery of goods where this issue is regulated in detail. With respect to the delivery of goods, the Rotterdam 
Rules make a distinction between a non-negotiable transport document (Article 45), a non-negotiable transport document that requires surrender (Article 46), and a negotiable transport document (Article 47). This corresponds to the practice that has developed in which in parallel to bills of lading, sea waybills are increasingly being used. In addition, the Rotterdam Rules envisage the use of non-negotiable transport documents that require surrender (Article 46), by which the use of straight bills of lading has been expressly recognized for the first time by an international convention. Adding to this complexity is Article 47(2) which entitles the carrier (under certain conditions) to deliver the goods without the surrender of a negotiable transport document.

The Rotterdam Rules do not give a precise definition of negotiable documents, focusing more on appearance and whether a document contains words such as "to order" or "negotiable", but failing to define the concept of negotiability. ${ }^{12}$ Since there is no universally adopted meaning of the term negotiable documents, obviously the Rotterdam Rules have left this issue to be determined by the governing law.

Article 47(2) contains several rules that apply "if the negotiable transport document expressly states that the goods may be delivered without the surrender of the transport document or the electronic transport record ..." This provision applies in cases where the holder of the document fails to claim the goods at the place of destination, or to identify himself in an appropriate way. In such cases, the carrier may ask for instructions from the shipper, or from the documentary shipper.

Subparagraph (b) provides that when the carrier delivers the goods upon instruction of the shipper or the documentary shipper in accordance with subparagraph 2(a) he will be "discharged from its obligation to deliver the goods under the contract of carriage to the holder, irrespective of whether the negotiable transport document has been surrendered to it ...".

Under subparagraph (c) the person giving instructions under subparagraph 2(a) "shall indemnify the carrier against loss arising from its being held liable to the holder". Under the same paragraph, the carrier may also refuse to follow those instructions if the person fails to provide adequate security as the carrier may reasonably request.

Under subparagraph (d) "a person that becomes a holder of the negotiable transport document or the negotiable electronic transport record after the carrier has delivered the goods pursuant to subparagraph 2(b) of this article, but pursuant to contractual or other arrangements made before such delivery, acquires

12 Article 1(15): “Negotiable transport document" means a transport document that indicates, by wording such as "to order" or "negotiable" or by some other appropriate wording recognised as having the same effect by the law applicable to the document, that the goods have been consigned to the order of the shipper, to the order of the consignee or to the bearer, and is not explicitly stated as being "nonnegotiable" or "not negotiable". 
rights against the carrier under the contract of carriage, other than the right to claim delivery of the goods".

Finally, subparagraph (e) provides that "a holder that becomes a holder after such delivery, and that did not have and could not reasonably have had knowledge of such delivery at the time it became a holder, acquires the rights incorporated in the negotiable transport document or negotiable electronic transport record".

\section{REACTIONS TO ARTICLE 47(2)}

There is an ongoing debate about Article 47(2).

The opinion of the International Federation of Freight Forwarders (FIATA) Working Group was very negative. The solution that a carrier can deliver the goods without the surrender of the negotiable document was termed "absolutely unacceptable".$^{13}$ This opinion also contains a warning about the potential risk of maritime fraud.

The position of the European Voice of Freight Logistics and Customs Representatives (CLECAT) was equally negative regarding Article 47(2). The article was qualified as "the most contradicting provision" which is "bound to create conflict and complicated international litigation".14

The view of the European Shippers' Council (ESC) was also negative. It expressed concern that Article 47(2) "could cause problems in relation to letters of credit"..$^{15}$

The opinion of the International Chamber of Shipping (ICS) was positive. It stated that Article 47(2) permits the carrier "to deliver the goods without presentation of the negotiable transport document while at the same time protecting the interests of all the parties involved". ${ }^{16}$

In academic debate, a negative attitude prevails. The text "Particular Concerns with Regard to the Rotterdam Rules" published by a group of world-renown scholars argues that when the goods are intended to be sold in transit "it would be wholly inappropriate to ask a shipper having sold the goods to a first buyer, for instructions with respect to delivery". ${ }^{17}$ The text also warns about the risk of maritime fraud. In another influential text, Anthony Diamond QC expre-

13 www.comitemaritime.org/Uploads/Rotterdam\%20Rules/3FIATA.pdf.

14 www.comitemaritime.org/Uploads/Rotterdam\%20Rules/4CLECAT.pdf.

15 www.uncitral.org/pdf/english/texts/transport/rotterdam_rules/ESC_PositionPaper_March2009.pdf.

16 www.uncitral.org/pdf/english/texts/transport/rotterdam_rules/ICS_PositionPaper.pdf.

17 The group includes J Alcantara, F Hunt, S O Johansson, A B Oland, K Pysden, J Ramberg, D G Schmitt, W Tetley and J Vidal: www.comitemaritime.org/Uploads/Rotterdam\%20Rules/Particular\%20concerns $\% 20-\% 20$ Rotterdam $\% 20$ Rules.pdf. 
sses a doubt that Article 47(2) can provide a solution to the problem of delivery without surrender of an original bill of lading..$^{18}$

There are also some favorable opinions. A group of authors which took active part in drafting the Rotterdam Rules tried to explain and justify the text of Article $47(2){ }^{19}$ Charles Debattista also takes a positive attitude stating that "Article 47(2) acknowledges the market reality that these hybrid documents are with us - and with us to stay". ${ }^{20}$

Since the initial criticism of the Rotterdam Rules, a group of scholars promoting the Rules has attempted to clarify the alleged misunderstanding of some provision in a text entitled "The Rotterdam Rules - An attempt to clarify certain concerns that have emerged" ${ }^{21}$ Here are the main points from this text that relate to Article 47(2).

... [I]f the goods are not deliverable the carrier may request instructions from the shipper in respect of delivery and, irrespective of the shipper still being the holder of the transport document or not, is discharged from any liability if it complies with such instructions.

The complaint that, pursuant to article 47(2), the carrier may issue a negotiable document that actually is not negotiable is not justified and is probably due to the failure to understand the purpose of this provision.

[The Rotterdam Rules] offer to the parties that know from the outset that the bill of lading will not be used in its intended ways, to relieve the carrier from the obligation of requesting surrender of the bill of lading.

... [I]t is the shipper itself that requests such statement precisely in order to ensure the possibility of delivery without presentation of the negotiable transport document ... article 47(2) just addresses the issue of non-presentation and tries to provide an alternative for the letter of indemnity system ... It is a false accusation that article 47(2) devaluates the value of the bill of lading system and that, therefore, the article 47(2) bill of lading is not a genuine bill of lading ... Article 47(2) just tries to provide a solution therefore, which is both practically and legally sound.

These arguments will be addressed below.

18 A Diamond QC “The Rotterdam Rules" (2009) LMCQ 445 at 521.

19 M F Sturley, T Fujita, G van der Ziel The Rotterdam Rules (Sweet \& Maxwell 2010); A von Ziegler, J Schelin and S Zunarelli (eds) The Rotterdam Rules 2008 (Kluwer Law International 2010); G van der Ziel "Delivery of the Goods, Rights of the Controlling Party and Transfer of Rights" (2008) JIML 597.

20 C Debattista "The Goods Carried - Who gets them and who controls them?" in UNCITRAL Colloquium on Rotterdam Rules (21 September 2009) www.rotterdamrules2009.com/cms/uploads/Def\%20 \%20tekst\%20Charles\%20Debattista\%2031\%200KT29.pdf.

21 F Berlingieri, P Delebecque, T Fujita and R Illescas (eds), www.comitemaritime.org/Uploads/Rotterdam\%20Rules/5RRULES.pdf. 


\section{DEVIATION FROM FUNDAMENTAL PRINCIPLES}

The drafters of the Rotterdam Rules obviously aimed at solving the problem of the delivery of goods when a negotiable document is not or cannot be surrendered. Under the existing rules, delivery should be made only against the surrender of a bill of lading. In practice, delivery is often made in exchange for a letter of indemnity.

The solution proposed under subparagraph (b) represents a substantial deviation from well-established rules and practice. There is no problem with requesting instructions from the shipper if he is still the holder of the document. The problem arises if the shipper is not the holder of the document. If the shipper is not the holder, this means that he is not the controlling party. This also means that such instructions have no binding character and the carrier is free to ignore them, for example if it is obvious that the instructions are wrong. What is not clear is how under subparagraph (b), the carrier can be discharged of delivery obligations against a lawful holder of the bill of lading on the basis of non-binding instructions of the shipper? This is quite puzzling. First, why would a carrier agree to follow the shipper's instruction and risk his liability under subparagraphs (d) and (e)? Second, why would the shipper bother to give instructions at all after he transferred the bill of lading to a transferee? Why would he risk potential liability under subparagraph (c) if the instructions were wrong? And why would he provide a security to the carrier for giving instructions that are not even binding?

Subparagraph (d) contains another enigma. According to this provision, a person that becomes the holder of the bill of lading after the carrier has delivered the goods "pursuant to contractual or other arrangements made before such delivery acquires rights against the carrier under the contract of carriage, other than the right to claim delivery of the goods". It is not clear what rights the holder of the document acquires against the carrier. ${ }^{22}$ One possible interpretation is that a person who has no right to delivery may sue the carrier for damages. ${ }^{23}$ This would mean that the carrier is discharged from an obligation to deliver the goods, but may not be discharged from liability for damages. Another question is whether the carrier can be discharged of liability for wrongful delivery? On the basis of subparagraph (c) which states that the person giving instructions under subparagraph (a) shall indemnify the carrier against the loss caused by being held liable under subparagraph 2, it can be concluded that the carrier might be held liable for wrongful delivery. So, under subparagraph (b) the carrier is discharged from

22 On the limited scope of holder's claims under art 47(2)(d), see E Rosaeg “New Procedures for Bills of Lading in the Rotterdam Rules" (2011) JIML 185.

23 According to $G$ van der Ziel, the main example of such a right is a claim for damages if the goods are delivered damaged or the delivery is short. However, it is not quite clear how a consignee could sue the carrier for damage to the goods or short delivery if the goods are delivered to someone else. 
his obligation to deliver the goods, even without surrender of the bill of lading, while under subparagraph (e) the carrier might be held liable for wrongful delivery. This sounds rather confusing: how can the carrier be discharged from an obligation to deliver the goods to the holder, and then be held liable for wrongful delivery against the holder? Does this text mean that under subparagraph (b), the carrier is not necessarily discharged of the obligation to deliver the goods, but can be so discharged? In order to avoid misunderstanding and confusion, these provisions should have been drafted in a clearer way.

Leaving aside this confusion, we enter into another: with respect to the carrier's liability, the relevance of the sentence "pursuant to contractual or other arrangements made before such delivery" is unclear. The carrier is normally not aware of "contractual arrangements" between the shipper and other holders of bills of lading (presumably under a contract of sale and documentary credit transactions), and such transactions, in principle, should not have an effect on the carrier's liability. However, the text of subparagraph (d) implies that the carrier's liability may depend exactly on such "contractual arrangements". In that case, why would the carrier risk liability against the party who acquired rights against the carrier pursuant to "contractual arrangements" made before delivery, when the carrier is not even in position to know the existence and contents of such "contractual arrangements"? Is it not safer for the carrier simply to follow the existing practice? Of course, under this scenario, which is the most reasonable from the carrier's perspective, Article 47(2) would lose its raison d'être.

Finally, according to subparagraph (e) "a holder that becomes a holder after such delivery" acquires the rights incorporated in the bill of lading. The problem is that this holder may not acquire the main right embodied in the bill of lading: the right to receive the goods from the carrier. The right to compensation that the holder would have against the carrier under subparagraphs (d) and (e) would not be the full compensation of loss, as the carrier would have the right to limit liability when delivery is made by duly following the provisions of Article 47(2). This would pose serious risk to the consignee, who would be able to receive only limited compensation, instead of the goods. So, Article 47(2) may bring new burdens to each of the parties: the shipper may risk liability for wrong instructions and may have to provide security to the carrier; the carrier would be held liable even if he followed the shipper's instructions in situations provided in subparagraphs (d) and (e); the consignee may come into position to receive only limited compensation from the carrier instead of the goods.

The claim that a document issued under Article 47(2) is a negotiable document is not sustainable. Article 47(2) identifies as a negotiable transport document a document that expressly states that the goods may be delivered without the surrender of the transport document. The term "negotiable" in this case is not 
just a misnomer; it is a contradictio in adjecto. In the case of negotiable transport documents, the delivery of the goods can be made only against the surrender of the document. Without this essential feature, a document can not be called a "negotiable document". On the other hand, delivery of the goods under instructions of the shipper and without surrender of transport document represents a typical feature of non negotiable documents. It can be argued that the document under Article 47(2) is a kind of "negotiable-minus document", or "non-negotiable-plus document", but certainly it is not a "negotiable document" in the sense that is firmly established in legal theory and practice.

The basic requirement of the rule contained in Article 47(2) is that the negotiable transport document expressly states that the goods may be delivered without the surrender of the transport document. This clause contravenes a fundamental feature of negotiable documents, as the presentation and surrender of a transport document is an essential ingredient of negotiable transport documents. One point has to be made clearly: the carrier is the party who, by receipt of the goods from the shipper at the port of loading, undertakes an obligation to deliver them to the lawful holder of the bill of lading at the port of destination. The carrier should not be concerned with "contractual arrangements" between the shipper and subsequent holders of the bill of lading. The carrier should also not be concerned with the fact of whether there were some "contractual arrangements" made before delivery, nor should he really care about the identity of the legal owner of the goods. The only thing that the carrier should care about with respect to delivery is that delivery has to be made to the lawful holder of the bill of lading. The rule that the goods are to be delivered only to the lawful holder of a bill of lading who must present it prior to delivery is essential to the function that the bill of lading performs as a document of title. One of the key functions of negotiable transport documents is enabling the transfer of the right to the delivery of the goods by transfer of the document itself. If the goods can be made deliverable without a negotiable transport document, this key function of negotiable documents would be compromised. The main value of the bill of lading in international trade is that it guarantees that the consignee, and nobody else, will get delivery of the goods. Article 47(2) undermines this role of the bill of lading as it opens the possibility that the goods can be delivered according to the shipper's instructions and that in such cases, the carrier will be discharged of the delivery obligation. In cases of wrongful delivery the consignee may have only a right to limited compensation against the carrier.

The attitude of the business community towards the delivery of the goods without a bill of lading has been very negative. This is reflected in the rules of P\&I clubs to deny indemnity to the carriers who deliver goods without the production of a bill of lading, as well as the fact that carriers are deprived of the be- 
nefit of liability limitation in such cases. Against such a background, Article 47(2) can be considered as an attempt to legalize a practice that has been considered as risky and exceptional, while it was considered as wrongful by the courts. ${ }^{24}$

\section{QUESTIONABLE RATIONALE}

It is difficult to grasp the rationale of Article 47(2). It seems that the assumption of the drafters was that the consignee often does not demand delivery and that in so doing, the consignee does not breach the contract of carriage. ${ }^{25}$ Another scenario is that the consignee fails to properly identify himself. Both situations are too rare in practice to serve as the basis for the rather exceptional rule expressed by Article 47(2). It is more likely for the consignee to not have yet received the document so that delivery is not possible. Debattista argues that under Article 47(2) "the holder must still possess the bill but need not surrender it for delivery of the goods" and that possession of the bill of lading is "manifested through presentation but not surrender". ${ }^{26}$ The author's reading of this provision is different. The main rationale for Article 47(2) is its application to situations when the consignee does not have the bill of lading at the moment the goods arrive at their destination, i.e. the consignee is not in possession of the bill and consequently cannot present it. This view is supported by subparagraphs 2(d) and 2(e), which expressly state that the holder becomes designated as such after the carrier has delivered the goods pursuant to subparagraph 2(b). In any event, what would be the logic behind a consignee presenting the bill and refusing to surrender it?

If the consignee has obtained a bill of lading, that normally means he has paid the contract price, so it would be strange if he did not demand the goods. The consignee may refuse to accept delivery only if the goods are so defective that it amounts to a fundamental breach, but this situation has nothing to do with delivery without a bill of lading. While a consignee may not be in breach of the contract of carriage for a failure to demand delivery, he may be in breach under the sale contract. ${ }^{27}$ In fact, the United Nations Convention on Contracts for the International Sales of Goods ("CISG") expressly provides for the buyer's obligation to take delivery (Article 60). The buyer has no right to reject the goods

24 Opinions regarding Article 47(2) that have been expressed by some professional associations, such as FIATA, can also be an indicator of the attitude of shipping-related businesses.

25 Von Ziegler et al “The Rotterdam Rules 2008” (n 19) 207.

26 ibid 146.

27 The United Nations Convention on Contracts for the International Sales of Goods, art 86(2) states that "[i]f goods dispatched to the buyer have been placed at his disposal at their destination and he exercises the right to reject them, he must take possession of them on behalf of the seller, provided that this can be done without payment of the price and without unreasonable inconvenience or unreasonable expense. This provision does not apply if the seller or a person authorized to take charge of the goods on his behalf is present at the destination ...". 
except under limited conditions as stated in the CISG, and certainly not for his own convenience; in that case the buyer himself may be held liable for the fundamental breach of contract.

Why would a shipper insist on inserting a clause into the bill of lading allowing delivery without a bill, if the problems related to the delivery without a bill of lading usually affect the consignee and the carrier rather than the shipper? By producing documents to a bank under the letter of credit, the shipper (the seller) has performed his obligation of delivery, and if there are problems at destination because the buyer failed to receive his transport document on time, that is a problem for the consignee (and the carrier). The situation might be different in charterparties, where the charterer may demand that the shipowner should deliver the goods without a bill of lading. This is because the seller, acting as the charterer, frequently sells the goods during a late stage of transit making delivery against the bill of lading difficult or even impossible. However, charterparties are based on the private autonomy of the parties and are expressly excluded from the scope of the Rotterdam Rules. ${ }^{28}$

The rationale for the shipper's instructions is also questionable. Article 47(2) is based on the assumption that the shipper has information on the consignee. While in some carriages the shipper may be aware of identity of the ultimate consignee, in many situations that is not the case. The typical cause of problems for failing to surrender the transport document at destination arises when the goods are resold in transit several times and, with the document procedure often lengthy, the documents can be delayed. Particularly in the commodity trade where the goods can be resold many times, the shippers often have no clue who the final holder of the goods may be. In such cases it makes no sense to ask the shipper for instructions with respect to delivery. In fact, in the most common case of delivery problems concerning goods without a bill of lading, the shipper's instructions under Article 47(2) have the lowest value. Or, to put in it a different way, the intended effect of the provision on the shipper's instructions would be least effective in the situations where it is most needed.

If the intention of this provision was to avoid problems related to delivery in exchange for a letter of indemnity, why does subparagraph (c) require the provision of a security? In this instance, the security should be provided by the shipper, and the carrier may refuse to follow the shipper's instructions if he fails to provide adequate security. So, the practice of giving security in the context of delivery is not avoided by Article 47(2). It simply provides a different scenario and reassignment of the role of providing security to the carrier; giving it to the shipper instead of to the consignee. While it is clear why the consignee would

28 The Rotterdam Rules expressly provide that the convention applies to liner carriage (art 1.3), and that it does not apply to the charterparty contracts (art 6.1). 
have an interest in providing such a security, it is far less clear why the shipper would do so.

If the transport document expressly states that the goods may be delivered without its document, this means that such a situation was envisaged at the moment the negotiable document was issued. Why then was a negotiable document issued at all? Would it not be better simply to follow the existing practice that non-negotiable documents are used in this kind of situation? Maritime practice has developed the use of the sea waybill to tackle the problem of delivery of the goods without the surrender of a transport document. The Rotterdam Rules have adopted this solution in Article 45. Was it really necessary to have in addition to non-negotiable documents, a new type of document that would be called "negotiable" but whose surrender would not be necessary?

Article 47(2) may also open the possibility of maritime fraud. The seller may sell the goods to another buyer leaving the first buyer with a claim against the carrier, who may not be liable for wrongful delivery if delivery was made according to the shipper's instructions. The shipper may also collude with the first buyer to defraud all subsequent buyers. If the goods are delivered without the production of a bill of lading, there is also a risk that the buyer who received the goods before payment is made can later refuse to pay because he has already obtained possession of the goods. Another danger is that the buyer can resell the goods by transferring the bill of lading to a new buyer, so that another party can present the bill of lading and claim the goods from the carrier.

It is true that in practice there are situations where the goods are delivered in exchange for a letter of indemnity, most often because the bill of lading is delayed. This is, of course, a serious problem. The attempt at solving this problem in Article 47(2) is not really a solution. By limiting the scope of Article 47(2) only to the cases where the transport document "expressly states that the goods may be delivered without the surrender of the transport document", the potential positive effects aimed at by this provision are substantially reduced; the problems of delivery without bill of lading would be avoided only in a very limited number of cases. As mentioned above, the intended effect of Article 47(2) would be least useful when most needed. The relatively modest positive effects that Article 47(2) may bring do not justify all the problems that this provision may create.

To be fair to the Rotterdam Rules, the role of a bill of lading is fully preserved in Article 47(1). The parties are free not to use Article 47(2). So, despite all criticism, Article 47(2) probably will not cause many problems in practice; in all likelihood, it will be used very rarely. 


\section{RELATION TO THE RIGHT OF CONTROL}

Chapter 9 of the Rotterdam Rules on the delivery of goods is closely related to chapter 10 which deals with the right of control. Article 50(1)(a) provides that the rights of the controlling party include the right to give instructions in respect of the goods. Further, Article 51(1)(a) provides that the shipper is the controlling party, except in a number of cases expressly referred to in this provision, which includes paragraph 3 of the same article that applies to the instance when a negotiable document is issued; in this case, the holder of the original negotiable document is the controlling party. After the shipper has sold the cargo to the first buyer in the chain, under Article 51 he has lost the status of the controlling party and is not authorized to give instructions to the carrier relating to delivery of the goods.

In order to avoid confusion, a distinction should be made between the instructions based on Article 47(2) and the instructions based on the right of control. A controlling party has the right to give instructions to the carrier based on his right of control, and this right is designed to protect persons having an interest in the cargo. The right of control can be very important for the shipper, since it enables him (as seller) to prevent delivery to a buyer who failed to pay the contract price. On the other hand, the instructions under Article 47(2) can only be given by a shipper or a documentary shipper when the carrier requests instructions from them.

According to Article 50(2) of the Rotterdam Rules "the right of control exists during the entire period of responsibility of the carrier, as provided in Article 12, and ceases when that period expires". On the other hand, the instructions based on Article 47(2) can only be given when the goods remain undelivered. The main purpose of these instructions is to remedy the problems that may arise when the goods cannot be delivered at their destination.

Under Article 52(1) of the Rotterdam Rules, the carrier has an obligation to comply with the instructions given by the controlling party. If the carrier fails to perform this obligation, he will be liable for losses caused by the breach..$^{29}$ On the other hand, under the text of Article 47(2) it seems that the carrier is not obliged to comply with the instructions from a shipper. Even if a carrier has sought instructions from the shipper, he still has the right not to follow those instructions where they are unreasonable and to take measures provided by Article 48(2) instead.

Several questions related to the right of control arise. If Article 51(3)(a) provides that the holder of the negotiable document is the controlling party, then why should the carrier seek instructions from the shipper? When the shipper is not the controlling party according to chapter 10 , but the controlling party is a

29 Rotterdam Rules 2008 art 52(4). 
transferee of the transport document pursuant to Article 57, on what legal basis can such a shipper, or documentary shipper, give instructions to the carrier? On whose behalf does the carrier hold the goods when a negotiable document is issued: on behalf of the shipper, or on behalf of the lawful holder of the negotiable document? When the shipper is not the controlling party, and does not have any authority regarding the goods, it is unclear how the instructions of such a party can discharge the carrier from his obligations embodied in a negotiable document.

An issue that may be related to the right of control is governed by article 28 which provides for cooperation between the carrier and the shipper, including giving instructions related to the handling of cargo and carriage. Does this obligation extend to the shipper's duty to provide instructions related to the delivery of goods? From the text it might be difficult to reach such a conclusion, unless "handling and carriage" is construed in a broad sense. Based on Article 29(1) which provides that the shipper will provide to the carrier "information, instructions and documents relating to the goods" that are necessary "[f]or the proper handing and carriage of the goods", it can be concluded that these instructions relate to the handling and carriage of the goods. But even though a broad interpretation would include instructions related to delivery of the goods, this does not mean that the shipper is the person who should give instructions related to the delivery of the goods after he has transferred the bill of lading.

\section{ARTICLE 47(2) IN THE CONTEXT OF CHARTERPARTIES}

Article 47(2) applies only when the transport document "expressly states that the goods may be delivered without surrender of the document". If the carrier is unable to locate the consignee, "the carrier may so advise the shipper and request instructions in respect of delivery of the goods". The holder of the document should therefore be aware that, if one of the situations mentioned in that provision occurs, the goods may be delivered on the basis of the instructions of the shipper in the event that the carrier is unable to obtain instructions from the consignee.

The impression is that the drafters were influenced by the practice that exists under some charterparties where the carrier has to obey the charterer's instructions with respect to delivery of the goods. ${ }^{30}$ Such a conclusion may be made based on illustrations used by the authors of the book The Rotterdam Rules (who were among the drafters of the Rules), ${ }^{31}$ in the discussion related to Article 47: each of the illustrations in this book referring to Article 47(2) makes reference to the char-

30 Von Ziegler et al “The Rotterdam Rules 2008” (n 19) 207.

31 M F Sturley, T Fujita, G van der Ziel The Rotterdam Rules (Sweet \& Maxwell 2010). 
terer acting as a shipper. ${ }^{32}$ In addition, Article 47(2)(c) resembles to a certain extent the employment and indemnity clause found in most time charter contracts. The drafters may have also had in mind the bill of lading clauses incorporating the charterparty terms.

Under time charter contracts, the master should act "under the orders and directions of the charterers as regards employment, agency and other arrangements" ${ }^{\prime 33}$ The charterer may wish to extend his authority by stating that he shall have the right to order the master to deliver the goods without a bill of lading. This is sometimes done in practice, and under certain conditions this right has been recognized by the courts. ${ }^{34}$ However, this situation under charterparties should be clearly distinguished from the contract of carriage governed by international conventions. This practice, which is valid in charter contracts where the freedom of contract prevails, may not be suitable for a contract of carriage carried out under a bill of lading. Charterparty contracts as part of private carriage are governed by different principles dominated by the principle of autonomy of the parties. Therefore, using such contracts as the model for regulating the issues that are to be governed by an international convention regulating the carriage of goods by sea may not be the best choice.

The identification of the charterer with the shipper can also be questioned, as it should be clear that the shipper and the charterer are not necessarily the same party. ${ }^{35}$ There is a clear distinction between the contract of carriage, which has the carriage of goods as its main subject matter, and the charter contract, which is basically a contract of hire with the use of a ship as its main subject matter. While in the case of time charter contracts, the charterer has the right to make orders to the master with respect to the voyage as part of "commercial management" throughout performance of the contract, the situation is completely different in contracts of carriage under bills of lading.

The relationship between the charterer and the shipowner in a charterparty contract is qualitatively different from the relationship between the shipper and the carrier. The relationship between the shipper and the carrier is based on the bill of lading, which is not a contract, but a document of title. While the shipper may also be the charterer, it is clearly wrong to have provisions related to the shipper assuming that the shipper is always the charterer. The application of Article 47(2) may lead to a situation in which the carrier requests instructions from the shipper when the shipper is not the charterer and has transferred the bill of

32 ibid 264, 269.

33 General Time Charter Party (Gentime) cl.12, New York Produce Exchange (NYPE) cl.8.

34 Enichem Anic SpA v Ampelos Shipping Co Ltd (The Delfini) [1990] 1 Lloyd's Rep 252.

35 Article 1(8) defines shipper as "a person that enters into a contract of carriage with a carrier". And the "contract of carriage" as defined in art 1(1) is clearly not a charterparty contract. 
lading. Clearly, in such a case, asking instructions from the shipper would contravene the fundamental principles on negotiable transport documents. After the shipper has transferred the negotiable document to a transferee, the contractual relationship between the shipper and the carrier is terminated and a new contractual relation between the carrier and the holder of the negotiable document is established. This is in clear contrast to charterparties where the shipper and the shipowner remain in a contractual relationship until the contract is terminated.

\section{THE HOUDA CASE LESSONS}

In most jurisdictions, the courts take the position that the shipowner must not deliver the goods other than against presentation of a bill of lading, even if he has been instructed by the charterer to make such a delivery. ${ }^{36}$ In The Houda case, ${ }^{37}$ the charterer ordered the shipowner to deliver the goods without a bill of lading, against a letter of indemnity countersigned by a bank, but the shipowner declined to accept this order. The court at first instance held that while under a time charter the charterer cannot lawfully order the shipowner or the master to deliver the cargo to a consignee who is not entitled to possession of the cargo, the charterer is not prevented from ordering delivery of the cargo without production of the bill of lading in circumstances where the charterer is entitled to possession of the cargo or gives an order with the authority of the person entitled to possession of the cargo. The Court of Appeal, however, took a different view and rejected the argument that a time charterer could order a shipowner to deliver the goods without production of an original bill of lading, even to a person who was entitled to possession of the goods. Lord Justice Millett examined the consequences of such a solution: ${ }^{38}$

But the real difficulty of the Judge's conclusion is that it leads to this: the charterers can lawfully require shipowners to deliver the cargo without presentation of the bills of lading if, but only if, the person to whom the cargo is delivered is in fact entitled to receive it. If that is indeed the law,

36 The Stetin (1889) 14 PD 142 at 147, A/S Hansen-Tangens Rederei III v Team Transport Corporation (The Sagona) [1984] 1 Lloyd's Rep 194, Kuwait Petroleum Corp v I \& D Oil Carriers (The Houda) [1994] 2 Lloyd's Rep 541, Motis Exports v Dampskibsellskabet AF 1912 [2000] 1 Lloyd's Rep 121, Allied Chemical International Corp v Comphania de Navegacao Lloyd Brasiliero [1986] AMC 826 (2d. Cir. 1985), C-Art Ltd v Hong Kong Island Lines America [1991] AMC 2888 (9th. Cir. 1991), Glencore Intenational AG v Owners of the "Cherry", Singapore High Court, Kan Ting Chiu J., April 2002 (available at: http//:onlinedmc.co.uk/ glencore_v_'cherry'.htm), International Harvester Co v TFL Jefferson 695 F. Supp 735 (S.D.N.Y. 1988), Cour d'Appel d'Aix, September 6, 1984 DMF, 157 (1986) , Ap. Paris 11 January 1985 DMF 166 (1986) (note by R Achard), Trib. Livorno 10 December 1986 Dir.Mar. 961(1987).

37 ibid (The Houda).

38 ibid (The Houda) at 558. 
it places the master in an intolerable dilemma. He has no means of satisfying himself that it is a lawful order with which he must comply, for unless the bills of lading are produced he cannot know for certain that the person to whom he has been ordered to deliver the cargo is entitled to it. One solution, no doubt, is that, since the master's duty is not of instant obedience but only of reasonable conduct, he can delay complying with the order for as long as is reasonably necessary to satisfy himself that the order is lawful, possibly by obtaining the directions of the Court in the exercise of its equitable jurisdiction to grant relief in the case of lost bills. But in my judgement the charterers are not entitled to put the master in this dilemma.

The point is, as Millett LJ states in the last sentence of the quote, that the charterer puts the master in a difficult situation. The master takes an obvious risk when he delivers the goods to a consignee who cannot produce the bill of lading. The question one may ask is whether the charterer may require the shipowner to take such a risk. Even though the shipowner may always require that the charterer puts up adequate security before he delivers the goods, to demand such security will, in most cases, be both more cumbersome and unreliable than demanding that the bill of lading be presented.

The claim that such a delivery is lawful if ordered by the person entitled to possession of the cargo contravenes the fact that the bill of lading is a document of title. It is a well-established principle that the carrier is bound to deliver the goods only to a lawful holder of the bill of lading, and he is not bound to investigate who is entitled to possession of the goods. When the consignee is not able to produce the bill of lading, the shipowner as carrier has the right to refuse the charterer's order of delivering the goods without the bill of lading, or to deliver the goods in exchange for a letter of indemnity that was offered to the shipowner in the present case. The most serious consequence of the first instance judgment in The Houda case would be that the carrier would no longer be justified in refusing to deliver the goods to a party who is not the lawful holder of the bill of lading, or in the case of a non-negotiable bill of lading, to a party who is not named in the bill of lading, when such a party is actually entitled to the goods. Such a radical change would endanger the role of the bill of lading as a document of title and discredit its commercial value. In addition, the carrier would be put in an extremely difficult position because he would be forced to judge whether the person to whom delivery is to be made under the charterer's order is entitled to possession of the goods.

This illustration from the charterparty contracts in the relationship between the charterer and the shipowner may serve as an indication of potential problems 
that could arise if the shipper were to be asked to give instructions to the carrier under a contract of carriage. Article 47(2) might make sense in the relationship between the charterer and the shipowner under a charterparty contract, and the outcome of The Houda case might have been different if there had been an express term in the charterparty entitling the charterer to order the owners to deliver the goods without a bill of lading. It is submitted that even in that case such clause would serve merely to protect the shipowner against the consequences of delivery of the goods without surrender of the bill; as a matter of principle the shipowner should not be bound by a clause that imposes an unlawful obligation on him. However, the Rotterdam Rules should not enter that area, because contracts under charterparties are expressly excluded from their scope.

\section{ARTICLE 47(2) AND INTERNATIONAL SALE}

Negotiable transport documents play an important role in international sale, so the new type of negotiable document under Article 47(2) would certainly have an impact on international sale. One of the intriguing questions that arises concerns the status of a negotiable transport document under Article 47(2) in relation to Article 58 of the CISG; can this document be considered a document "controlling the disposition of the goods" in the sense of Article 58 of the CISG? According to Martin Davies, the drafters of the CISG likely "had in mind the traditional, negotiable bill of lading issued by an ocean carrier, which is the paradigm document controlling the right to possession of the goods it represents". ${ }^{39}$ A document under Article 47(2) equally likely does not meet this description. The fact that the goods may be delivered without the surrender of a negotiable transport document clearly compromises its negotiable character and capacity to control disposition of the goods.

While a negotiable transport document under Article 47(1) qualifies as a document "controlling disposition of the goods", a negotiable transport document under Article 47(2) is not a negotiable document in the full sense of the CISG, since disposition of the goods is not carried out on the basis of the document itself, but on the basis of the shipper's instructions. This kind of disposition of goods, as well as delivery without the surrender of a transport document, is typical for non-negotiable documents which do not control disposition of the goods, since this is done by the shipper's instructions to the carrier.

Hence, the "negotiable transport document" under Article 47(2) is not negotiable in the full sense, and as long as disposition of the goods is carried out on

39 M Davies "Documents that Satisfy the Requirements of CISG Art. 58" (papers from Uniform Sales Law: the CISG at its 30th Anniversary, a conference in memory of Albert H Kritzer, 12-13 November 2010, Belgrade) The Annals of the Faculty of Law in Belgrade - Belgrade Law Review, Year LIX (2011) no. 3, 39-66. 
the basis of the shipper's instructions, it is not a document that controls disposition of the goods in the sense of Article 58 of the CISG.

Regardless of its impact on the CISG, Article 47(2) would have serious consequences on international sale. It is clear that a buyer would not be obliged to pay for the goods in return for a document which states that the delivery of the goods can be made without its surrender, since the seller presenting such a document would be in breach of his delivery obligation. The document under Article 47(2) would also not meet the requirements for delivery documents under CFR/ CIF Article 8 of the INCOTERMS 2010, which provides for the document which must "enable the buyer to claim the goods from the carrier at the port of destination" and "enable the buyer to sell the goods in transit by the transfer of the document to a subsequent buyer or by notification to the carrier". Obviously, a document which expressly provides that the goods can be delivered under the instructions of a party which is not in possession of the negotiable document does not fit the INCOTERMS definition of the "delivery document". The expression "notification to the carrier" relates to electronic documents where delivery is controlled by the party which is in possession of a "private key" or other similar device which replicates the function of a negotiable document. The right to give notification cannot be in the hands of a party which does not have control over the private key or similar device. Hence, Article 47(2) does not meet the requirements of the INCOTERMS rules with respect to the delivery document and it would create problems in the event of electronic bills of lading, as an electronic procedure which would not give one party the exclusive right to payment or delivery would clearly not be acceptable.

Similar problems would arise under letters of credit. Article 20 of the UCP 600 does not provide for this kind of bill of lading, so if the Rotterdam Rules enter into force the UCP would have to be revised. Needless to say, the banks would be reluctant to make payment under a letter of credit against such a document without the express authorization of the buyer. Even in that case, the banks would have to be vigilant, as this kind of document does not provide collateral security. It appears that the drafters of the Rotterdam Rules failed to make proper assessment of all these negative consequences which would have a detrimental effect on international sale. Adoption of the Rotterdam Rules would also create the need for amendments in a number of regulations related to international sales.

\section{CONCLUSION}

A challenging road lies ahead for the Rotterdam Rules. One of the potential problems is related to the way the Rotterdam Rules were drafted. After the task of the unification of maritime law was transferred from the CMI to the UN and its 
agencies, it became impractical and maybe even impossible to make amendments by revision, as with the Visby Rules. The most efficient and practical way would be simply to revise a number of provisions from the Hague-Visby Rules, such as abolishing the nautical fault exception and adding a few more provisions, such as those related to electronic documents. However, it would be difficult to expect UNCITRAL to take such action, even though technically it was possible for the Rotterdam Rules to have been just a revised version of the Hague-Visby Rules. UNCITRAL generally has a preference for a more comprehensive approach, which is demonstrated by the text of the Rotterdam Rules. As a result, the Rotterdam Rules contain 96 articles and 18 chapters, compared to the 16 articles of the Hague Rules.

The Rotterdam Rules added a number of new issues, such as the right of control, delivery of goods, transfer of rights and volume contracts. The text might be not only too long, but also too complex and too complicated to be suitable for use in practice. Commercial practice needs clarity and has a natural preference for simple over complicated texts. Moreover, some provisions, such as Article 47(2), are highly controversial as has been demonstrated.

Article 47(2) arguably is controversial in the sense that this provision contravenes some well-established principles on negotiable documents. Admittedly, the rule that the consignee must present a negotiable document prior to delivery is outmoded and can cause problems in practice. Nevertheless, the delivery of goods without a bill of lading is something that should be avoided as unlawful and risky. The drafters of the Rotterdam Rules have attempted to find a solution to this problem. However, the suggested solution may undermine the value of the bill of lading as one of the key documents in international trade. If purchasers and banks feel that they can no longer rely on bills of lading as negotiable documents of title, to paraphrase Lord Justice Pearce in the Brown Jenkinson case "the disadvantage to the commercial community would far outweigh any convenience provided by delivery of the goods without bills of lading". ${ }^{40}$ Why would parties abandon the current practice they are familiar with to adopt a new way of doing things that is risky and full of loopholes? Radical reforms are typically motivated by a need to solve urgent problems. It is highly questionable whether such a need existed in this case, and it is even more questionable whether Article 47(2) can solve the problems persisting. In the author's view, the Rotterdam Rules would look much better without Article 47(2).

The goal of uniformity is a worthy one and the efforts of the drafters of the Rotterdam Rules deserve respect. Instead of unifying the rules that govern the carriage of goods by sea, however, the Rotterdam Rules may end up being just

40 Brown Jenkinson v Percy Dalton (London) Ltd [1957] 2 Q.B. 621. The text in italics is mine paraphrasing the original text which reads "the giving of clean bills of lading against indemnities". 
another convention that exists in parallel with all previous ones, which would mean that this convention instead of contributing to the unification of law, in fact, may create more fragmentation in the international regime governing the carriage of goods by sea and further undermine its uniformity. Under the existing text of the Rotterdam Rules, the road towards the stated goals has too many holes for one to feel comfortable with the proposed solution. It is a bumpy road that eventually may create more problems than it can solve.

Sažetak:

\section{ČLANAK 47(2) ROTERDAMSKIH PRAVILA: RJEŠENJE STARIH PROBLEMA ILI STVARANJE NOVIH?}

Roterdamska pravila je nova konvencija u materiji međunarodnog prijevoza stvari morem, koju je usvojio UNCITRAL 2008. godine. Ova konvencija po proi puta regulira nekoliko pitanja koja nisu bila regulirana prethodnim konvencijama u ovoj oblasti, kao što su predaja stvari i pravo kontrole nad stvarima tijekom prijevoza. Ambiciozni i inovativni pristup Roterdamskih pravila privukao je pažnju stručne javnosti, te doveo do žive međunarodne debate u kojoj su razmijenjeni brojni argumenti i iznesena suprotstavljena mišljenja. Svrha ovoga članka je da doprinese toj debati obrađujući pitanje načina reguliranja predaje stvari u Roterdamskim pravilima. Glavna pažnja je posvećena članku 47(2), koji je jedna od najkontroverznijih odredaba Roterdamskih pravila. U članku su detaljno obrađena pitanja koja se odnose na način na koji je članak 47(2) regulirao pitanje predaje stvari, te na posljedice koje ovakva odredba može imati na međunarodni prijevoz stvari morem, kao i na pitanja vezana za međunarodnu prodaju robe.

Ključne riječi: međunarodne konvencije; prijevoz stvari morem; prijevozne isprave: vrijednosni papiri; predaja stvari. 
